\title{
Comparison between saps 3 and APACHE II in surgical patients admitted to a brazilian ICU
}

\author{
RS Nunes ${ }^{1 *}$, EA Nicolini ${ }^{2}$, MG Menegueti ${ }^{2}$, MA Ferez ${ }^{1}$, M Auxiliadora-Martins ${ }^{2}$, A Basile-Filho ${ }^{2}$ \\ From ESICM LIVES 2015 \\ Berlin, Germany. 3-7 October 2015
}

\section{Introduction}

Prognostic models are used for mortality predictions and illness severity assessment. Acute physiology and chronic health evaluation II (APACHE II) and simplified acute physiology score II (SAPS 3) are the most commonly used models worldwide. The performance of prognostic score needs to be validated before its use.

\section{Objectives}

The aim of this study was to compare the discriminatory power of two prognostic scores, SAPS 3 and APACHE II, in surgical patients.

\section{Methods}

Retrospectively collected data from all surgical patients admitted to a Brazilian hospital ICU between January 2011 and December 2013 were analyzed. The standardized mortality ratio (SMR) was computed for mortality prediction. The predictive ability of the APACHE II and SAPS 3 to differentiate survivors and non-survivors was determined by the ROC curve.

\section{Results}

The data were collected of 1599 surgical patients. The mean ICU and hospital length of stay was 2.94 and
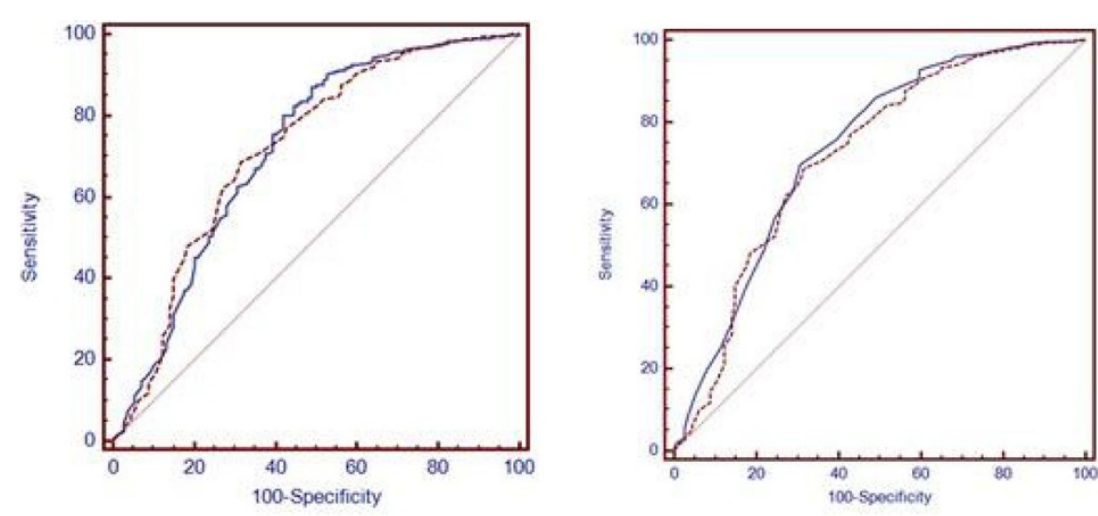

Figure 1 Acute Physiology and Chronic Health Evaluation II. 
11.82 days, respectively. ICU mortality was $7.12 \%$. Mortality predicted by customized SAPS-3 was $15.4 \%$ (SMR of 0.46 ) and mortality predicted by APACHE-II was $13.1 \%$ (SMR of 0.54). Discrimination was good and there was no statistically significant difference between the ROC curve of these scores: the area under the ROC curve of customized SAPS-3 was $0.716(0.693-0.738)$ and the area under the ROC curve of APACHE II was 0.702 (0.679-0.725).

\section{Conclusions}

In this group of surgical ICU patients, the performance of SAPS 3 and APACHE II were similar.

\section{Authors' details}

${ }^{1}$ Hospital São Francisco, Ribeirão Preto, Brazil. ${ }^{2}$ Hospital das Clínicas da

Faculdade de Medicina de Ribeirão Preto - USP, Ribeirão Preto, Brazil.

Published: 1 October 2015

doi:10.1186/2197-425X-3-S1-A836

Cite this article as: Nunes et al: Comparison between saps 3 and

APACHE II in surgical patients admitted to a brazilian ICU. Intensive Care

Medicine Experimental 2015 3(Suppl 1):A836.

\section{Submit your manuscript to a SpringerOpen ${ }^{\circ}$ journal and benefit from:}

- Convenient online submission

- Rigorous peer review

- Immediate publication on acceptance

- Open access: articles freely available online

- High visibility within the field

- Retaining the copyright to your article

Submit your next manuscript at $\gg$ springeropen.com 